\title{
Analysis of the Effect of Operational Profitability and Debt to Asset Ratio (DAR), Debt to Equity (DER) on Tax Avoidance. Empirical studies on Food and Beverage Sub-sector Manufacturing Industry companies are listed on the Stock Exchange in 2014-2017
}

\begin{abstract}
Feber Sormin.
Mercu Buana University, Jakarta Indonesia

Abstract

This study aims to find out and test the effect of Profitability with Proxy Return on Assets (ROA), Debt to Asset Ratio (DAR), Debt to Equity Ratio (DER) to Tax Avoidance with research samples to be tested in population research are manufacturing companies listed on the Jakarta Stock Exchange with sub Food and beverages from 2014 to 2017 through secondary data collection collected from the company's financial statements. The method used in selecting samples is purposive sampling. The basic criteria for sampling companies used are: (1) Food and Beverage sub-manufacturing companies listed on the Jakarta Stock Exchange from 2014 to 2017. (2). Companies that publish financial statements from the year under study. The reason for choosing food and beverage sector manufacturing companies is because the achievement of tax revenues from this sector every year has fluctuated or fluctuated, and companies in this sector have survived in the current economic crisis. The data obtained is processed by multiple linear regression analysis using SPSS statistical tools, with the output target to be achieved in this study can be published in international journals. Based on the results of the analysis and discussion that has been done, it can be concluded that profitability is partially Profitability has a significant influence on tax avoidance. Partially Debt to Asset Ratio (DAR) Debt to Asset Ratio (DAR) has a significant influence on tax avoidance. Debt to Equity (DER) partially Debt to Equity (DER) does not have a significant effect on tax avoidance. Simultaneously that there is an influence between Profitability, Debt to Asset Ratio (DAR), and Debt to Equity (DER) on Tax Avoidance in the Food and Beverage Sub-Sector Manufacturing Industry company listed on the
\end{abstract} Stock Exchange in 2014-2017.

Key Word: Profitability of Return on Assets (ROA), Debt to Asset Ratio (DAR), Debt to Equity Ratio (DER), Tax Avoidance

DOI: $10.7176 / \mathrm{EJBM} / 11-16-13$

Publication date:June $30^{\text {th }} 2019$

\section{Introduction}

Tax Revenue is one of the important components as a source of state revenue where its usefulness is very important in financing the national development process and for funding the need for expenditure in running the wheels of Government. In Law No. 28 of 2007 article 1 paragraph (1) states that Tax is a compulsory contribution to the state owed by an individual and an entity that is of a nature based on the Law by not getting compensation directly and used for state needs for as much as possible prosperity people.The development of an increasingly advanced and diverse economy but until now Tax revenues have become the mainstay of the government in financing development and Government expenditures, have not reached what is expected to be able to support the financing of State expenditure in accordance with the mandate of the State Expenditure Budget (APBN) that has been jointly established between state administrators and people's representatives in the House of Representatives (DPR / MPR). So that the Government, especially in the field of the Minister of Finance and the Directorate General of Taxation, is one of the government departments tasked with seeking internal state revenues. In seeking state revenue from taxes that have been budgeted, the Directorate General of Taxes must try to adjust government policies such as tax regulations and must be able to keep up with the rhythm of the development of the taxpayer's business. Many Government efforts are made to increase this Tax Revenue, such as implementing tax reforms consistently and continuously, improving services to taxpayers in the form of ease of reporting, payment, and ease of access to tax information, improving the effectiveness of counseling and public relations in order to increase mandatory awareness and compliance taxes, increase the extensification, intensification, and enforcement of tax laws, improve the effectiveness of inspection and collection, increase the capacity of the Directorate General of Taxes (DGT) which includes strengthening human resources, information technology, and budgets, utilizing the results of tax amnesty policies, namely expanding the tax base and increasing tax compliance and identifying and 
extracting tax potential with international cooperation, as well as implementing financial information disclosure programs for tax purposes.

However, taxpayers are still often found to make some tax resistance efforts to minimize tax burdens in various ways, both ways that are still in accordance with taxation regulations (legally) such as tax planning such as tax avoidance, or inappropriate tax or illegal regulations such as tax smuggling tax avasion). (Pohan, 2013: 8) states that efforts to minimize tax carried out by taxpayers are referred to as tax planning.

Following is the target table and realization of tax revenues from $2014-2017$ :

Tabel 1.1

Tax Revenus

\begin{tabular}{|l|l|l|l|l|l|}
\hline \multicolumn{1}{|c|}{ Year } & \multicolumn{1}{c|}{$\mathbf{2 0 1 3}$} & \multicolumn{1}{c|}{$\mathbf{2 0 1 4}$} & $\mathbf{2 0 1 5}$ & $\mathbf{2 0 1 6}$ & $\mathbf{2 0 1 7}$ \\
\hline Target & 1.148 .364 & 1.246 .106 & 1.489 .255 & 1.539 .166 & $1.472,7$ \\
\hline Realization & 1.077 .306 & 1.146 .865 & 1.240 .418 & 1.284 .970 & $1.339,8$ \\
\hline$\%$ & $\mathbf{9 3 , 8 1 \%}$ & $\mathbf{9 2 , 0 4 \%}$ & $\mathbf{8 3 , 2 9 \%}$ & $\mathbf{8 3 , 4 8 \%}$ & $\mathbf{9 0 , 9 8 \%}$ \\
\hline
\end{tabular}

Source: Government financial report

Based on the description of table 1.1 from 2013 to 2017, the level of the value of tax revenue in Indonesia has not yet achieved as expected / targeted, even though the various efforts have been made by the institutional part which is regulated by tax revenues.

Tax avoidance, often thought to be one of the causes of not achieving tax revenue. This is because taxpayers try to minimize the tax that must be paid through tax avoidance. This action is carried out by the taxpayer to pay less than the amount that should be paid to the tax authority. Tax evasion cases involving first class companies. This time it involved one of the companies in the Coca-Cola Company group, PT Coca-Cola Indonesia (CCI). PT CCI is alleged to have circumvented the tax resulting in a lack of tax payments worth Rp.49.24 billion. The search results of the Directorate General of Taxes (DGT), the Ministry of Finance, found that there was a large swelling of costs that year. The large cost of expenses causes taxable income to decrease, so that the tax deposit decreases. These costs include advertising from the 2002-2006 period with a total of Rp. 566.84 billion. That's for advertising beverage products into the Coca-Cola brand. As a result, there is a decrease in taxable income. According to the DGT, the total CCI taxable income for that period was IDR 603.48 billion. Whereas the CCI calculation, taxable income is only IDR 492.59 billion. With this difference, DGT calculates a shortfall of Rp. 49.24 billion in CCI income tax. For DGT, this cost is very suspicious and leads to the practice of transfer pricing to minimize taxes. Transfer pricing is a transaction of goods and services between several divisions in a business group with prices that are not reasonable, so that the tax burden decreases. This practice can be detected if there are activities that are not in accordance with the company's business. PT CCI's products are concentrates, not ready-to-drink products. However, they have to spend a lot of money on advertising. "The advertising costs charged by PT CCI do not have a direct connection with the products produced," said Edward Sianipar, DGT representative at the hearing on Thursday (06/12/2014). Naturally, advertising costs are borne by other Coca-Cola companies. Just so you know, Coca-Cola Indonesia is divided into three companies, namely those that focus on concentrating, packaging and distribution. https://ekonomi.kompas.com/read/2014/06/13/1135319/Coca-Cola.

Experts, argue that there are many factors that have not yet achieved tax revenue as the target has been made, one of which is tax avoidance by taxpayers, which can result in not achieving state revenues as expected. This taxpayer action can be categorized as a tax resistance through actions to practice tax avoidance through utilization. Sometime, tax avoidance or tax uncompliance have reacted by investor and tax compliance is not (Tarmidi, 2019)

Harry Graham Balter quoted in the Taxation Management book (2005: 49), said "Tax smuggling implies as an effort made by taxpayers - whether successful or not - to reduce or completely eliminate tax debts that are not based on tax laws applicable, while tax avoidance is the same business, which does not violate the provisions of tax laws and regulations ". According to Robert H. Anderson quoted and translated by Mohammad Zain in the Taxation Management book (2005: 50) explains: "Smuggling of taxes is smuggling taxes that violate tax laws, while tax avoidance is a way to reduce taxes that are still within the limits of regulatory provisions tax laws and can be justified, especially through tax planning. ". Some factors that influence why taxpayers do Tax Planning (Tax Planning), among others, influenced by Corporate Governance, company size, company age, executive character, profitability, leverage, financial lease and other things. According to I Gusti Ayu Cahya Maharani and 
Ketut Alit Suardana (2014) stated that there are several factors that influence management to carry out tax avoidance practices namely corporate governance, profitability, and executive characteristics. Giawan Nur Fitria (2018) states that company size has an effect on tax avoidance. This can be interpreted as the greater the company the more company assets. Asset of the company increases making operational costs borne by the company even greater. For this reason, the company will try to make tax savings through tax avoidance in order to minimize the tax costs paid by companies. Waluyo (2017) mentioned that the Audit Committee and Audit Quality have positively influenced tax avoidance on banking companies listed on the Indonesia Stock Exchange. the role of the Audit Committee and Quality Audit has been involved in making decisions to implement tax avoidance. On the other hand, the role of the Board of Commissioners Proportion and Institutional Ownership has a negative effect on tax avoidance.

One of the factors that influence tax avoidance is influenced by profitability. Profitability describes the ability of companies to earn profits through all available resource capabilities such as sales activities, cash, capital, number of employees, number of branches, and so on (Sofyan Syafri Harahap (2008: 219), while according to Brigham and Houston $(2006 ; 107)$, Profitability is the net result of a series of policies and decisions that can be determined by calculating various relevant benchmarks through analyzing financial conditions, operating results and the level of profitability of a company. In this case, the profitability ratio consists of Gross profit margin (GPM), Operational Profit Margin (OPM), Net Profit Margin (NPM), Return on Assets (ROA), Return on Investment (ROI), Return on Equity (ROE), Income Rate for common stockholders (return on Common stock Equity), Earning per Share ( EPS) or Revenue per share of ordinary shares, Basic earnings Power (BEP). In this case, the researcher uses the independent variable of profitability that is pro with Return on Assets (ROA). Return on Assets (ROA) is the profitability ratio that shows the percentage of profits (net income) obtained by the company in relation to the overall resources or the average number of assets. ROA is a ratio that measures how efficient a company is in managing its assets to generate profits during a period. ROA is expressed as a percentage (\%). The purpose of acquisition / investment in company assets is how to generate income and of course also generate profits or profits for the company itself. Return on Assets can help management and investors to see how well a company is able to convert its investment to assets into profits or profits (profit). Previous research conducted by Fitria Maharani Al Rozi (2017) in the Consumer Goods Industry company listed on the IDX stated that Return On Assets (ROA) had a significant negative effect on tax avoidance as measured by the cash effective tax rate. Mardiah Nursani, Diamonalisa, Edi Sukarmanto (2017) states that "Profitability proxied by Return On Assets (ROA) has an effect on tax avoidance". Rusli Reinaldo (2017) states that leverage, Return On Assets (ROA), has a significant effect on tax avoidance. While in the Scania study (2016) states that ROA does not affect the effective tax rate. Fajar Arif $\mathrm{F}$ (2017) research also mentions that in the research results, ROA and Leverage do not affect tax avoidance.

Another factor that affects tax avoidance is to look at the ratio in terms of debt financing which is described by Capital (Equity) or often referred to as Leverage Ratio which is proxied by Debt to Asset Ratio (DAR). Debt To Asset Ratio (DAR) is a debt ratio used to measure the ratio between total debt and total assets, meaning how much the company's assets are financed by company debt. In the research Citra Janiencia Setiani (2016) states that Debt to Asset Ratio has a significant positive effect on tax avoidance. So, the lower the debt used in financing company assets, the company tends not to try to avoid tax evasion. Whereas Wastam (2018) states that profitability, leverage, and sales growth can affect the existence of tax avoidance activities.

Other Influence Factors of Leverage Ratio are proxied by Debt to Equity Ratio (DER). This ratio is known by comparing between all debts, including current debt with all Equity. This DER is very useful to find out the amount of funds prepared by the borrower as collateral for debt. Safirra Salsa Nabilla's research, Faith Zulikri (2018) in an empirical study of food and beverage sub-sector manufacturing companies listed on the Indonesian Stock Exchange, said that Leverage proxy by Debt to Equity Ratio (DER) has a positive effect on tax avoidance, the higher the company's risk, leverage ( Debt to Equity Ratio) will cause the increase in tax avoidance. In Research by Mardiah Nursani, Diamonalisa, Edi Sukarmanto (2017) states that "Leverage proxied by Debt to Equity Ratio (DER) affects tax avoidance", while Deddy Dyas Cahyono's Research, Rita Andini and Kharis Raharjo (2016) mention that Leverage (DER) does not affect tax avoidance.

Based on DGT tax receipts data, we can know the food and food sector tax revenue in 2012 amounted to 32,730 and 4,078, in 2013 the food sector tax revenue was 35,870 and the beverage sector amounted to 4,496, in 2014 the food sector tax revenue was 34,443 and the drinks sector was 5,415, in 2015 food sector tax receipts amounted to 38,994 and the beverage sector amounted to 5,106, in 2016 food sector tax revenues amounted to 35,198 and the beverage sector amounted to 5,982. Tax receipts in the food sector from 2012 to 2013 increased 9.5\%, from 2013 to 2014 decreased by $3.9 \%$, from 2014 to 2015 increased by $13.2 \%$, from 2015 to 2016 decreased by $9.7 \%$. And tax revenue in the beverage sector from 2012 to 2013 has increased by $10.3 \%$, from 2013 to 2014 it has increased by $20.4 \%$, from 2014 to 2015 has decreased $5.7 \%$, from 2015 to year 2016 increased by $17.1 \%$.

This research is planned to be carried out in the Food \& Beverages sub-sector which has gone public and is listed on the Indonesian Stock Exchange in the period 2014-2017. Consideration of sample selection of food and 
beverage industry, in addition to the increase in tax revenues, Industry food and beverage is one of the best and can survive for the domestic market, this is likely because the products produced are the primary and secondary needs of every human being. In this research plan using tax avoidance as the dependent variable and the independent variable in the form of Profitability (return on assets (ROA), Debt to Asset Ratio (DAR), and Debt To Equty Ratio (DER). This study is: "ANALYSIS OF THE EFFECT OF PROFITABILITY, DEBT TO ASSETS 
RATIO (DAR) AND DEBT TO EQUITY RATIO (DER) ON TAX AVOIDANCE (Empirical Study of Manufacturing \& Food \& Beverages) on the IDX for 2014-2017)

\section{Framework for Research and Hypothesis}

Based on the theoretical and previous research describes above, several factors can influence the existence of tax avoidance as follows:

\section{Effect of Profitability on Tax Avoidance}

Profitability ratios are proxy by Return on assets (ROA) which can provide an overview of the net profit / net profit obtained from the use of assets. If the higher return on assets ratio, then the higher the profit generated by the company. From this, it will trigger the practice of tax avoidance, where taxpayers will try to reduce the company's tax burden

ROA is a ratio that measures how efficient a company is in managing its assets to generate profits during a period. ROA is expressed as a percentage (\%). Return on Assets can help management and investors to see how well a company is able to convert its investment to assets into profits or profits (profit). Previous research conducted by Fitria Maharani Al Rozi (2017) in the Consumer Goods Industry company listed on the IDX stated that Return On Assets (ROA) had a significant negative effect on tax avoidance as measured by the cash effective tax rate. The results of research conducted by Mardiah Nursani, Diamonalisa, Edi Sukarmanto (2017) state that "Profitability proxy by Return On Assets (ROA) affects tax avoidance". Ida (2016), which states that return on assets has a positive effect on tax avoidance. And other research conducted by Deanna (2017) which states the results that return on assets have a negative effect on tax avoidance. Whereas the research conducted by Scania (2016) results that ROA does not affect the effective tax rate.

\section{Effect of Debt To Asset Ratio (DAR) on Tax Avoidance}

Debt To Asset Ratio (DAR) is one of the ratios to measure the solvency level of a company, namely to see the company's ability to pay long-term obligations. Debt To Asset Ratio (DAR) is a debt ratio used to measure the ratio between total debt and total assets, meaning how much the company's assets are financed by company debt. A company that is said to be solvable if the company has sufficient assets and wealth to pay its debts. Citra Janiencia Setiani (2016) states that Debt to Asset Ratio has a significant positive effect on tax avoidance. So, the lower the debt used in financing company assets, the company tends not to try to avoid tax evasion. While Wastam (2018) states that leverage can affect the existence of tax avoidance activities.

\section{Effect of Debt To Equity Ratio (DER) on Tax Avoidance.}

Leverage ratio which is proxied by Debt to Equity Ratio (DER) is known to be able to compare all debt, including current debt with all Equity Debt to equity ratio, which is a ratio used to measure the proportion of debt to capital. This ratio is calculated as the quotient between total debt and capital. This ratio is useful to find out the magnitude of the ratio between the amount of funds provided by creditors and the amount of funds coming from the owner of the company. Hery (2016). The results of research conducted by Mardiah Nursani, Diamonalisa, Edi Sukarmanto (2017) state that "Leverage proxied by Debt to Equity Ratio (DER) has an effect on tax avoidance". The results of this study are different from the research of Deddy Dyas Cahyono, Rita Andini and Kharis Raharjo (2016) stating that Leverage (DER) does not affect tax avoidance. Whereas the Safirra Salsa Nabilla Research, Faith Zulikri (2018) in an empirical study of the food and beverage sub-sector manufacturing companies listed on the IDX, said that Leverage proxied by Debt to Equity Ratio (DER) has a positive effect on tax avoidance, the higher the company's risk, leverage (Debt to Equity Ratio) will lead to increased tax avoidance. Based on the explanation above about the effects of tax avoidance, the framework of this study was formed. This frame of mind describes the relationship between variables. The following is the research framework shown in Figure 2.1. 
Figure 3.1

Logical framework

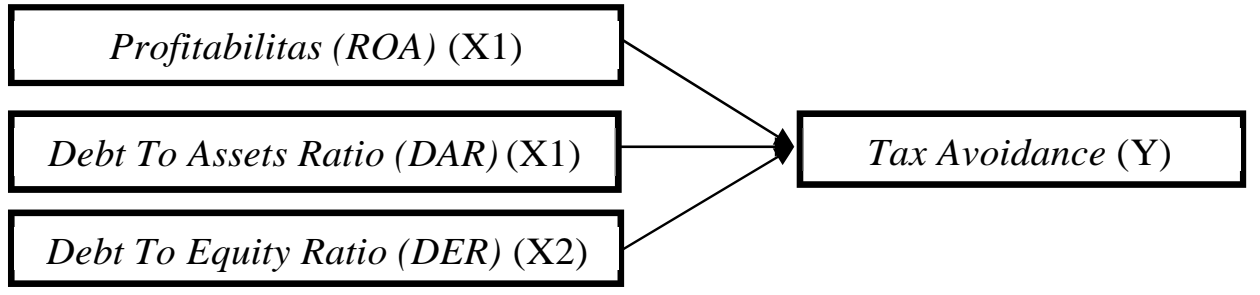

]

Hypothesis

Based on the description above, the hypothesis one in this study can be formulated as follows:

H1 = Profitability Ratio which is proxied by Return on Assets Ratio (ROA)

affect tax avoidance.

H2 = Debt to Asset Ratio (DAR) has an effect on tax avoidance.

H3 = Debt to Asset Ratio (DER) has an effect on tax avoidance.

III. Research.Method

A. Time and Place of Research

The data used in this study are financial reports on the food and beverage sub-sector manufacturing industry companies listed on the Stock Exchange in 2014 until 2017. This research was conducted through financial statement data presented on the website of Philips Sekuritas Indonesia at https: // www .poems.co.id /, where PT. Phillip Sekuritas Indonesia is one of the official Trading companies which provides information on financial statements of companies listed on the IDX.

\section{B. Research Design}

According to Erwan Agus Purwant, Dyah Ratih Sulistyastuti (2011; 25), research design (research design) is a plan about how a study will be conducted. Research Design is a procedure guideline as well as a technique in research planning that is useful as a guide or reference for developing strategies that produce research models or blue print, Hasibuan, Zainal.A (2007). The design of this study is to examine the effect of profitability which is influenced by ROA and leverage that is proxied by Debt To Asset Ratio (DAR) and Debt to Equity Ratio (DER) to tax avoidance in the food and beverage sub-sector manufacturing companies listed on the Indonesia Stock Exchange in 2014 up to 2017. This type of research is included in the criteria as a Causal Comperative Research study or causal research using a method Experimentation is by controlling independent variables that will affect the dependent variable on the planned situation.

\section{Definition and Operation of Variables}

Operational definitions are carried out to provide any empirical references that can be found in the field to describe precisely the concept in question so that the concept can be observed and measured. A concept described in certain concept definitions will not be observed or measured in the field. To be able to observe or be measured, a concept must be operationally defined, Erwan Agus Purwanto, Dyah Ratih Sulistyastuti (2011: 18). What is a variable in a study is determined by its theoretical foundation, and is confirmed by the Research Hypothesis. Therefore, if the theoretical foundation is different, the research variables will also be different, Sumadi Suryabrata (1983: 25). Variable definition Variables can be interpreted as something that will be the object of research observation. Variables are also called factors that play a role in the events or symptoms that will be studied. Sumadi Suryabrata (1983: 25). According to Sugiyono (2016: 38) states the research variable is everything in the form of what is determined by the researcher to be studied so that information can be obtained about it, then conclusions are drawn. In this study using two types of variables, namely the independent variable $(\mathrm{X})$ and the dependent variable (Y) with a ratio scale. The sample that will be used is in the food and beverage sub-sector manufacturing industry companies listed on the Stock Exchange in 2014 - 2017.

\section{a. Dependent Variable (Y)}

Erwan Agus Purwanto, Dyah Ratih Sulistyastuti (2011: 17) states that the dependent variable or dependent variable is the variable that is influenced by the independent variable. In this study the dependent variable used is tax avoidance. Andi Priandoyo (2016) said that the measurement of tax avoidance can be used with the Effective Tax Rate (ETR) model, which can reflect the fixed differences between book calculations and fiscal profits through 
their calculations based on the company's financial statements. If the higher the effective value of the tax rate is generated, the avoidance practices that occur will be lower. The formula for calculating the Effective Tax Rates is:

Effective Tax Rate (ETR)

$=\frac{\text { Total Tax Expense }}{\text { Total Tax Income }}$

b. Independent Variable (X)

Erwan Agus Purwanto, Dyah Ratih Sulistyastuti (2011: 17) states that Independent Variables or independent variables are often called Predictors, which are variables that influence or cause changes in the dependent variable. Independent variables are variables that are not bound or independent variables that affect other variables. Independent variables are variables that influence or are the cause of changes or the emergence of variables dependent (bound) (Sugiyono, 2016: 39). In this study the independent variables used include profitability which is proxied by Return on Assets (ROA) and Debto to Assets Ratio (DAR), Debt to Equity Ratio (DER). The following is an explanation of the independent variables in general as follows:

1. Profitability (Return On Asset). (X1)

Arthur J.Keown; John D. Martin; J William Petty; David F. Scott, Jr. (2008: 80) states, Return on Assets (ROA) or return on assets determines the amount of net income generated from company assets by connecting net income to total assets. Return on Assets is a return on assets that can be used as an indicator of company profitability, that is, returns on assets equal to net income divided by total assets. According to Kasmir (2015) states that return on assets is a ratio that shows the return on total assets used in companies to generate profits. If the higher return on assets ratio, then the higher the profit generated by the company. Furthermore, according to Brigham (2014: 148) suggests that return on assets is a ratio of net income to total assets. The indicator of measuring Return On Assets (ROA) is by the formula:

$$
\text { ROA }=\frac{\text { Net Profit After tax }}{\text { Total Assets }} \times 100 \%
$$

2. Debt to Asset Ratio (Debt Assets) / DAR. (X2)

One type of leverage ratio is Debt to Asset Ratio (DAR). Debt To Asset Ratio (DAR) is one of the ratios to measure the solvency level of a company, namely to see the company's ability to pay long-term obligations. A company that is said to be solvable if the company has sufficient assets and wealth to pay its debts. Therefore, the Debt To Asset Ratio (DAR) is also a debt ratio used to measure the ratio between total debt and total assets, meaning how much the company's assets are financed by the company's debt. According to Syamsuddin (2006: 30) Debt to Total Assets Ratio (DAR) is used to measure how much the company's assets are financed by total debt. The higher this ratio means the greater the amount of loan capital used for investment in assets to generate profits for the company. Citra Janiencia Setiani (2016) states that Debt to Asset Ratio has a significant positive effect on tax avoidance. The lower the debt used in financing company assets, the company tends not to try to avoid tax evasion. The indicator used to measure Debt to Asset Ratio (DAR)is:

Debt to Asset Ratio $(\mathrm{DAR})=\frac{\text { Total Hutang }}{\text { Total Assets }} \quad$ x $\quad 100 \%$

D. Population and Study Samples

1. Population

According to Sugiyono (2016: 80) states that the population is a region of generalization consisting of objects / subjects that have certain qualities and characteristics set by researchers to be studied and then conclusions drawn. The population in this study was conducted at the food and beverage sub-sector manufacturing industry companies listed on the Indonesia Stock Exchange from 2014 to 2017 taken from the Jakarta Stock Exchange website.

2. Samples 
The sample is part of the number and characteristics of the population (Sugiyono, 2016: 81). Sampling techniques are generally divided into Random Sampling or Probability sampling and Non Random Sampling or Nonprobability sampling. Non Probability sampling or Non-random Sampling means individuals or units taken from populations deliberately chosen according to certain considerations. This type of sample is divided into purposive sampling, snowballing sampling, systematic sampling (quasi random sampling), quoata sampling. Erwan Agus Purwanto, Dyah Ratih Sulistyastuti (20111). In this study researchers used Purpusove sampling, which is sampling based on research requirements, meaning that each unit / individual taken from the population is deliberately chosen based on certain considerations. Purposive sampling is a technique of determining samples with certain considerations (Sugiyono, 2016: 85). The criteria for this research sample data are as follows:

a. Food and Beverage sub-sector manufacturing companies listed on the Indonesia Stock Exchange for the period 2014-2017

b. Companies that consistently publish financial reports for the period 2014-2017

E. Data Collection Techniques

Given this research is quantitative research, using secondary data research (existing statistics) through the technique of collecting data using the documentation method. The documentation technique in this study is the method carried out by collecting data, identifying and reviewing secondary data in the form of financial reports in the food and beverage sub-sector manufacturing industry companies listed on the Stock Exchange for the period 2014-2017. And data collection in this study was obtained from several sources such as: previous studies, journals, previous theses, books and information obtained from the internet related in this study. In this study the data used is secondary data by examining the report. finance of the food and beverage sub-sector manufacturing companies listed on the Indonesia Stock Exchange in $2014-2017$

F. Analysis Method

A process of testing data after the selection and collection of research data is often referred to as the Analysis Method Step. The data analysis method used is multiple linear regression with data analysis techniques in this study, namely descriptive and causal statistics. It is hoped that this analysis can give an understanding of which independent variables are related to the Dependent variable (bound), and also to know the forms of the relationship. Data processing Research will use SPSS (Statistical Package For The Social Scenario). 1. Descriptive Statistics Analysis

According to Sugiyono (2016) descriptive statistics are statistics used to analyze data by describing or describing data that has been collected as it is without intending to make conclusions that apply to the general or generalizations. Thus descriptive statistical analysis is expected to be able to provide an overview of data selected from the amount of data $(\mathrm{N})$, minimum data value, maximum data value, average (mean), standard deviation (Ghozali, 2013). Through this descriptive statistical analysis will be able to provide an overview and characteristics of the data sampal used in the study.

2. Test of Classical Assumptions

Classical assumption testing is done before testing hypotheses with multiple linear regression analysis and simple linear regression. This classic assumption testing is intended to test or ascertain the feasibility of a regression model which is then carried out to test the research hypothesis. The classic assumption test consists of normality test, multicollinearity test, autocorrelation test, and heteroscedacity test (Ghozali, 2013).

a. Normality Test using Kolmogorov-Smirnov analysis on statistical analysis programs such as SPSS.

The Kolmogorov-Smimov method uses significant values at 0.05 , namely:

1. If a significant score is generated $>0.05$ then the data

normal distribution and $\mathrm{Ha}$ accepted.

2. If the significant score produced is $<0.05$ then the data is not normally distributed and Ha rejected.

b. Autocorrelation TestThe autocorrelation test used is the Durbin-Watson statistical test, lagrange multiplier test, stastic Q test, and run test (Ghozali, 2013).

c. Multicollinearity TestAccording to (Ghozali, 2013) the multicolinearity test aims to test whether the regression model found a correlation between independent variables (free). A good regression model should not have a correlation between the independent variables. A common cutoff value is used to indicate the presence of multicollinearity if:

1. Tolerance value $\leq 0.10$, multicollinearity occurs.

2. Tolerance value $>0.10$ so there is no multicollinearity.

3 . VIF value $\geq 10$, multicollinearity occurs. 
4. VIF value $<10$, there is no multicollinearity.

Bd. Heteroskedastity test

A regression model containing the problem of heteroscedasticity means that the variable variance in the model is not constant. The diagnosis of heteroscedasticity is a spearman ranking correlation test. This compliment uses the " $t$ " distribution by comparing the value of $t$ count with $t$ table. If the value of $t$ count is greater than $t$ table then reject $\mathrm{HO}$ and accept $\mathrm{Ha}$, meaning the regression model contains a problem of heteroscedastity, Erwan Agus Purwanto, Dyah Ratih Sulistyastuti (2011).

Heteroscedasticity test aims to test whether in the regression model there is an inequality of variance from the residual one observation to another observation. A good regression model, namely homoskedasticity or heteroscedasticity does not occur (Imam Ghozali, 2013). According to Imam Ghozali (2013), one way to detect heterokesdastistas is to look at scatter plots between standardized residuals (* SRESID) against standardized predicted value (* ZPRED) where the $\mathrm{Y}$ axis is $\mathrm{Y}$ that has been predicted, and the $\mathrm{X}$ axis is residual (Y prediction$Y$ really) that has been studentized. Basic decision making (Imam Ghozali, 2013):

a. If there are certain patterns such as dots that have a certain pattern regularly (wavy, widened and then narrowed) then indicates heterokedastistasd.

b. If there is no clear pattern and there are no spreading spots above and below number 0 on the $\mathrm{Y}$ axis there is no heterokedastistas

\section{Model Suitability Test}

Model suitability test is a test that is carried out to see the compatibility or suitability of observations that come from a distribution. Statistically, at least this can be measured from the coefficient of determination, the statistical value $\mathrm{F}$ and the statistical value $\mathrm{t}$. Statistical calculations are statistically significant if the statistical test values are in a critical area (the area where Ho is rejected). Conversely if it is not significant if the statistical test value is in the area where Ho is accepted (Ghozali, 2013).

There are several types of model suitability tests used as follows:

\section{a. $\quad$ Double Correlation Test $(\mathrm{R})$}

Double Correlation Test $(\mathrm{R})$ is used to find out the relationship between two or more independent variables on the dependent variable simultaneously. This coefficient shows how much the relationship occurs between independent variables simultaneously towards the dependent variable (Dependent variable). The value of $\mathrm{R}$ ranges from 0 (zero) to 1 (one), the value closer to 1 (one) means the relationship that occurs between the independent variables with the Dependent variable gets stronger, and vice versa when approaching 0 (zero), the relationship between variables Free with the dependent variable getting weaker. Sugiyono (2007) provides interpretation of the correlation coefficient as follows:

0,00 to $0,199=$ Relationship X1, X2, X3 ... etc. with Y Very low.

0.20 to $0.399=$ Relationship X1, X2, X3 ... etc. with Y Low.

0.40 to $0.599=$ Relationship X1, X2, X3 ... etc. with Medium Y.

0.60 to $0.799=$ Relationship X1, X2, X3 ... etc. with Strong Y.

0.80 to $1,000=$ Relationship X1, X2, X3 ... etc. with Y Very Strong.

\section{b. Determination Coefficient Test (R2)}

Analysis of the coefficient of determination (R2) is used to determine or measure the percentage of how far the influence of Indenpendent Variable (X) simultaneously on Dependent variables (Y). The coefficient of determination is between 0 (zero) to 1 (one). If the value of R2 is 0 (zero) or below 0 (minus), it means that there is no ability of the independent variable or no effect in explaining the dependent variable, but if $\mathrm{R} 2$ is greater than 0 or the value is very small, then the ability of the dependent variable is very low explaining the relationship with Dependent variable. Whereas, if the R2 value approaches 1 (one), it means that the independent variable used gives almost all the information needed to predict the variation of the dependent variable. However, R2 must increase if there is an additional one independent variable regardless of whether the variable significantly influences the dependent variable. Therefore, many researchers recommend using the value R2 (Ghozali, 2013).

\section{b. Simultaneous Test or Regression Coefficient Test together (Test F}

The F statistical test is used to determine whether the Independent variable (X1, X2, X3) jointly influences the Dependent variable by looking at the $\mathrm{F}$ test value. This needs to be done to find out whether the regression model can be used to predict the dependent variable or not. Significant (Sig.) Indicates that there is a relationship that occurs that can be used for the population (Can be Generalized), meaning that by taking a small sample of the 
population, the sample taken can represent the total population. The stage of conducting an $\mathrm{F}$ test can be done with (Duwi Consultant: 2011), through the following steps:

1) Formulate a Hypothesis.

Ho $=$ There is no effect of independent variables $(\mathrm{X} 1, \mathrm{X} 2, \mathrm{X} 3)$ on the dependent variable (Y) together. $\mathrm{Ha}=$ There is an influence of independent variables on the dependent variable together.

2) Determine the level of significance used ( $\mathrm{eg} \mathrm{a}=5 \%$ or 0.05 significant for the research standard).

3) Determine $F$ count. (see table obtained by $F$ count from the result of ANOVA column " $F ")$.

4) Determine F Table. By using a 95\% confidence level, a $=5 \%$, df 1 (number of variables -1 ) $=2$, df 2 (n-K-1) $(\mathrm{n}=$ Number of Samples, $\mathrm{K}=$ Number of Independent Variables). Determining F Tables can be calculated on their own, for example using Ms Exel by using a formula. 5) Testing Criteria. Or by comparing between F Count with table F, with the following conditions:

If $\mathrm{F}$ count $<\mathrm{F}$ table, then $\mathrm{Ho}$ is accepted. If $\mathrm{F}$ count $>\mathrm{F}$ table, then $\mathrm{Ha}$ is accepted.

6) Comparing F count with F table, with criteria: suppose value F count $>\mathrm{F}$ table, then $\mathrm{H} 0$ is rejected.

7) Conclusion of the results of the analysis. The criteria for example is if F count $>\mathrm{F}$ table, then $\mathrm{H} 0$ is rejected, meaning that there is an effect of the Independent variable on the dependent variable together.

8. This step is repeated one by one according to the number of independent variables used in the study. Whereas according to the basic criteria for decision making for statistical tests $t$ as follows (Ghozali, 2013): Determining a significant level $(\alpha)$ that is equal to $5 \%$ can be done based on the probability value, by means of decision making are:

1. If the probability value is $>0.05$ then Ho is accepted

2. If the probability value is $<0.05$ then Ho is rejected

Or by looking at table $t$, with the following conditions:

1. If - $\mathrm{t}$ table $<\mathrm{t}$ count $<\mathrm{t}$ table, then Ho is accepted

2. If - $t$ count $<-t$ table or $t$ count $>t$ table, then Ho is rejected

To calculate the t-table, the provisions of $n-1$ are used at a significant level $(\alpha)$ of $5 \%$ (error rate of $5 \%$ or 0.05 ) or $95 \%$ confidence level or 0.95 , so if the error rate of a variable is more than $5 \%$ it means that the variable is not significant

b. Multiple Linear Regression Test

In multiple linear analysis is an independent variable used to predict the value of the dependent variable (Ghozali, 2013). Multiple regression test is used to test the effect of Profitability and DAR, DER on tax avoidance.

The relationship between these variables can be described by the equation as follows:

$$
\mathrm{ETR}=\alpha+\beta 1 \mathrm{ROA}+\beta 2 \mathrm{DAR}+\beta 3 \mathrm{DER}+\mathrm{e}
$$

$\begin{array}{lll}\text { Dimana : } & & \\ \text { ETR } & : & \text { Tax Avoidance } \\ \alpha & : & \text { Konstanta Persamaan Regresi } \\ \beta 1-\beta 3: & \text { Koifisien variabel independen } \\ \text { ROA } & : & \text { Return On Asset. } \\ \text { DAR } & : & \text { Debt to Asset Ratio. } \\ \text { DER } & : & \text { Debt to Equity Ratio. } \\ \text { e } & : & \text { Error }\end{array}$

5. Data Analysis

Descriptive statistics aim to find out the number of data, minimum values, maximum values, (mean) average values, and standard deviations from all studies during the 4 observation periods of 2014-2017. 
Tabel 1

Statistik Descriptive test

Descriptive Statistics

\begin{tabular}{|l|r|r|r|}
\hline & \multicolumn{1}{|c|}{ Mean } & Std. Deviation & \multicolumn{1}{|c|}{ N } \\
\hline TaxAvoidance &, 26882 &, 053967 & 28 \\
ROA &, 08581 &, 039764 & 28 \\
DAR &, 38931 &, 147930 & 28 \\
DER & 1,88026 &, 381946 & 28 \\
\hline
\end{tabular}

Normalitiy test
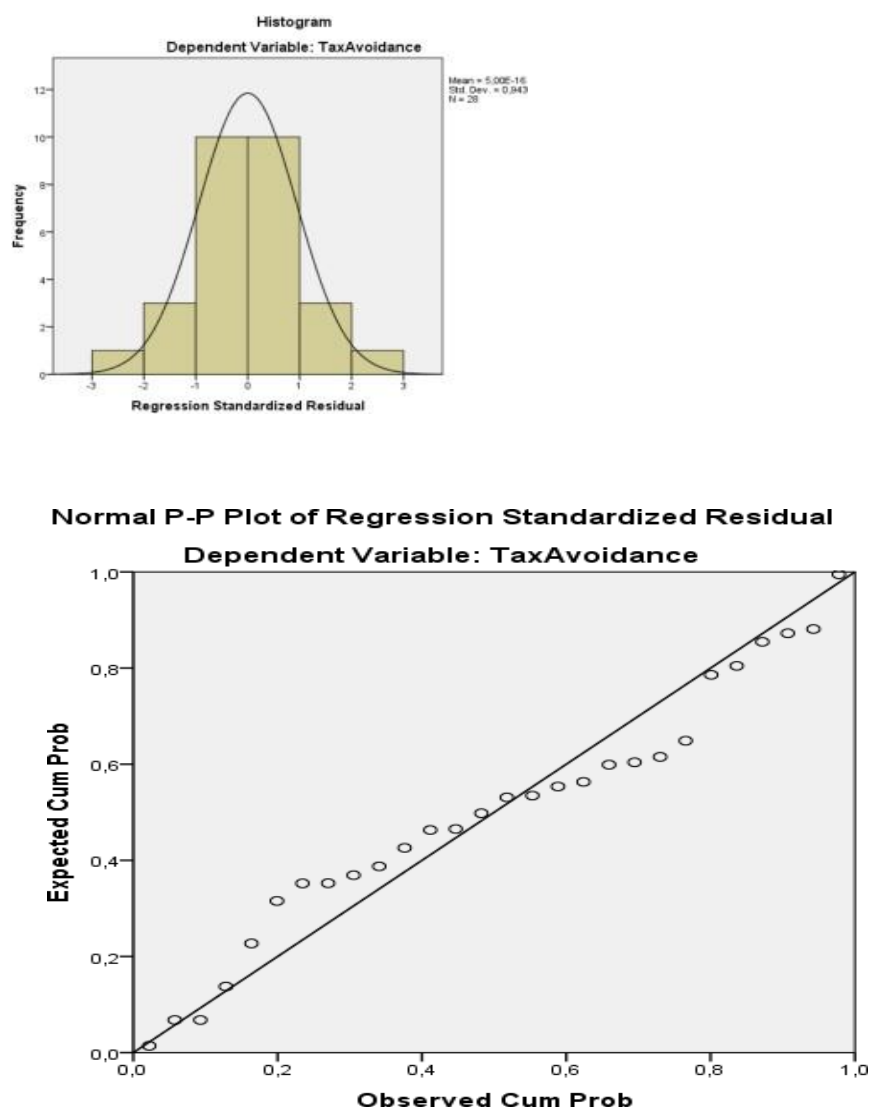

One-Sample Kolmogorov-Smirnov Test

\begin{tabular}{|c|c|c|}
\hline & & $\begin{array}{c}\text { Unstandardized } \\
\text { Residual }\end{array}$ \\
\hline \multirow{3}{*}{$\begin{array}{l}\mathrm{N} \\
\text { Normal Parameters }\end{array}$} & & 28 \\
\hline & Mean & ,0000000 \\
\hline & Std. Deviation & ,04286745 \\
\hline \multirow{2}{*}{ Most Extreme Differences } & $\begin{array}{l}\text { Absolute } \\
\text { Positive }\end{array}$ & $\begin{array}{l}, 129 \\
, 128\end{array}$ \\
\hline & Negative &,- 129 \\
\hline Kolmogorov-Smirnov Z & & ,684 \\
\hline Asymp. Sig. (2-tailed) & & ,738 \\
\hline
\end{tabular}

a. Test distribution is Normal.

b. Calculated from data. 
Testing this classic assumption includes the normality test aims to test whether normally distributed data is proven from the results of histogram charts with bell-shaped curves, probability plot charts as evidenced by points that spread around diagonal lines that follow a diagonal line, and the last normality test with see from the results of the kolmogorov-smirnov test as evidenced by the asymp.sig (2-tailed) value of 0.738 above 0.05 .

Table 3 : Multikoloniality

Coefficients $^{\mathbf{a}}$

\begin{tabular}{|c|c|c|c|c|c|c|c|c|}
\hline \multirow{2}{*}{\multicolumn{2}{|c|}{ Model }} & \multicolumn{2}{|c|}{ Unstandardized Coefficients } & \multirow{2}{*}{$\begin{array}{c}\begin{array}{c}\text { Standardized } \\
\text { Coefficients }\end{array} \\
\text { Beta }\end{array}$} & \multirow[t]{2}{*}{$\mathrm{t}$} & \multirow[t]{2}{*}{ Sig. } & \multicolumn{2}{|c|}{ Collinearity Statistics } \\
\hline & & B & Std. Error & & & & Tolerance & VIF \\
\hline \multirow{4}{*}{1} & (Constant) & ,317 & ,078 & & 4,070 & 000 & & \\
\hline & ROA &,- 663 & ,282 &,- 488 & $-2,348$ & 027 & ,608 & 1,644 \\
\hline & DAR &,- 316 &, 111 &,- 865 & $-2,845$ & ,009 &, 284 & 3,517 \\
\hline & DER &, 070 & 047 & ,495 & 1,488 &, 150 & ,238 & 4,207 \\
\hline
\end{tabular}

a. Dependent Variable: Tax Avoidance

In a good regression model there should not be perfect or near perfect correlation between the independent variables. The significance of multicollinearity is that the correlation coefficient is not certain and the error is very large. The way to find out whether or not there are symptoms of multicollinearity in general is to look at the value of Variance Inflation Factor (VIF) and Tolerance, if the VIF value is less than 10 and tolerance is more than 0.1 then multicollinearity does not occur. Based on the results of multicollinearity testing on the independent variables of this study, the tolerance value of the three independent variables is greater than 0.10 . The Inflation Factor Variance (VIF) value of the three independent variables is smaller than 10. Based on the predetermined criteria that have been previously stated, it can be concluded that there is no multicollinearity problem among the independent variables, so the multicollinearity test is fulfilled.

\section{Fiqure1: hetesroskedastisitas}

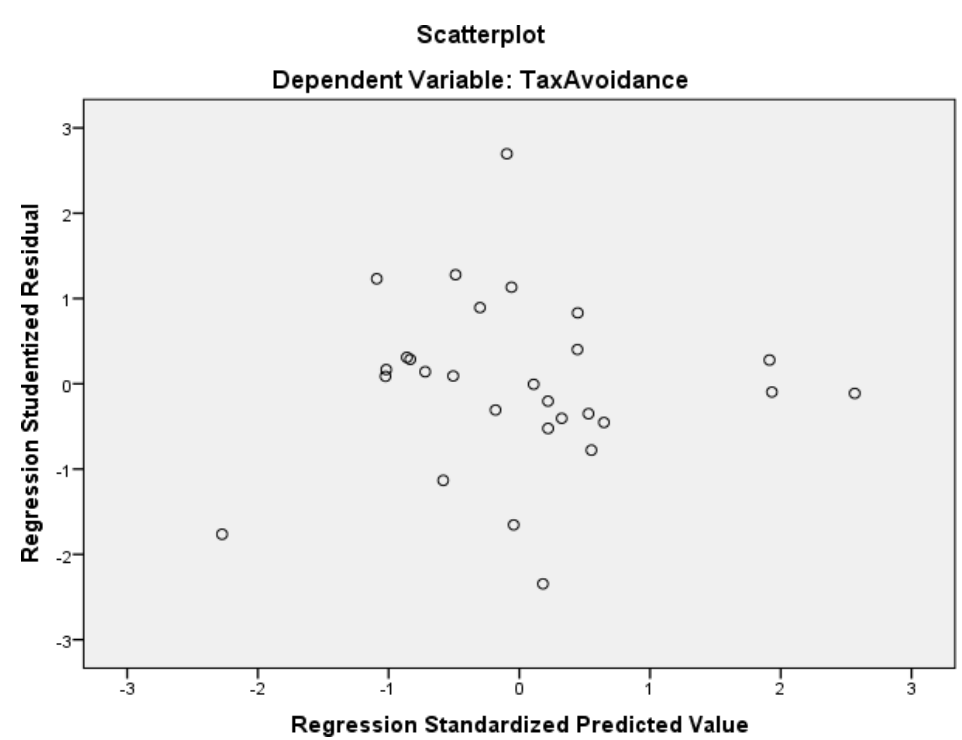

Heteroscedasticity is a residual variable that is not the same in all observations in the regression model. In good regression there should not be heteroscedasticity. Criteria for determining whether heteroscedasticity has occurred or not that sounds if there is no clear pattern, and the points spread above and below the Y axis number, there is no heteroscedasticity. In this study, the scatterplot graph shows a good regression model in accordance 
with the rules of heteroscedasticity

Table 4: Results of the Determination Coefficient (R2)

The coefficient of determination is used to determine the ability of the independent variable in explaining the dependent variable. The value for the coefficient of determination can be seen in the Adjusted column. R-Square

\section{Model Summary ${ }^{b}$}

\begin{tabular}{|l|r|r|r|c|}
\hline Model & \multicolumn{1}{|c|}{$\mathrm{R}$} & R Square & \multicolumn{1}{c|}{$\begin{array}{c}\text { Adjusted R } \\
\text { Square }\end{array}$} & $\begin{array}{c}\text { Std. Error of the } \\
\text { Estimate }\end{array}$ \\
\hline 1 &, $607^{\mathrm{a}}$ &, 369 &, 290 &, 045468 \\
\hline
\end{tabular}

a. Predictors: (Constant), DER, ROA, DAR

b. Dependent Variable: Tax Avoidance

Based on the table above, it can be seen that the coefficient of $\mathrm{R}$ is 0.607 with an Adjusted $\mathrm{R}$ Square value of 0.290 or $29.0 \%$. Table 5: Simultaneous Significance Test Results (Test F)

The following is a table of simultaneous test results (F) between Profitability, Debt to Asset Ratio (DAR), and Debt to Equity (DER) to Tax Avoidance.

\section{ANOVA ${ }^{a}$}

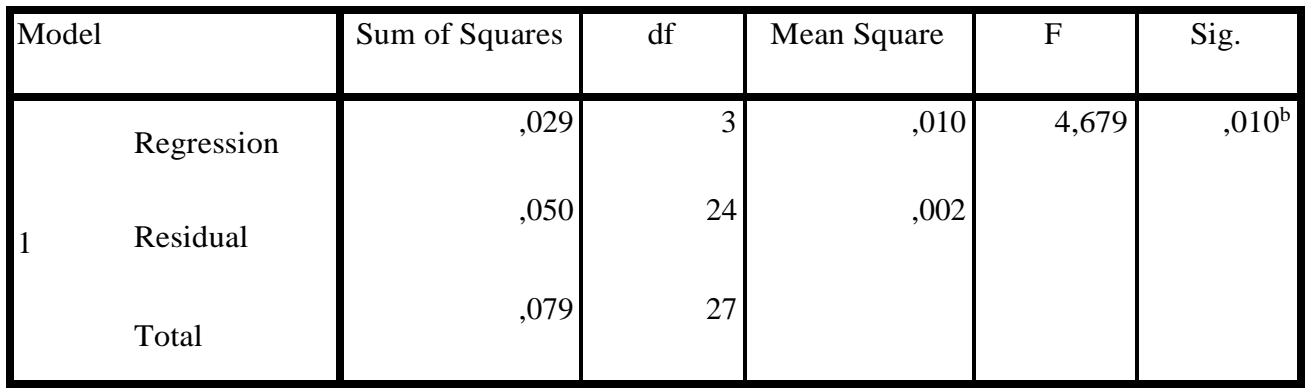

a. Dependent Variable: TaxAvoidance

b. Predictors: (Constant), DER, ROA, DAR

pased on the results of the table above, it can be seen that the simultaneous test value ( $\mathrm{F}$ test) is 4.679 with a sign value of 0.010 .

Table 6: Individual Parameter Significance Test Results (t Test)

The following is a partial test result table $(\mathrm{t})$ :

Coefficients $^{\mathbf{a}}$

\begin{tabular}{|c|c|c|c|c|c|c|}
\hline \multirow{2}{*}{\multicolumn{2}{|c|}{ Model }} & \multicolumn{2}{|c|}{ Unstandardized Coefficients } & \multirow{2}{*}{$\begin{array}{c}\text { Standardized } \\
\text { Coefficients } \\
\text { Beta }\end{array}$} & \multirow[t]{2}{*}{$\mathrm{t}$} & \multirow[t]{2}{*}{ Sig. } \\
\hline & & $\mathrm{B}$ & Std. Error & & & \\
\hline \multirow{4}{*}{1} & (Constant) & ,317 &, 078 & & 4,070 &, 000 \\
\hline & ROA &,- 663 & ,282 &,- 488 & $-2,348$ & ,027 \\
\hline & DAR &,- 316 &, 111 &,- 865 & $-2,845$ & ,009 \\
\hline & DER & ,070 &, 047 & , 495 & 1,488 &, 150 \\
\hline
\end{tabular}


Based on the table above, it can be seen that the partial test value ( $\mathrm{t}$ test) between Profitability to tax avoidance is 2,348 , with a sign value of 0.027. Partial test value ( $t$ test) Debt to Asset Ratio (DAR) to tax avoidance is 2.845 and sign value is 0.009 . And the partial test value ( $t$ test) Debt to Equity (DER) to tax avoidance is 1,488 and the sign value is 0,150 .

\section{Discussion Effect of Profitability on Tax Avoidance.}

Based on the t test the Profitability variable has a tcount of 2.438 greater than ttable 2.05954 with a significant value of 0.027 smaller than the significant value that has been determined which is 0.05 . This shows that Ha1 is accepted and $\mathrm{Ho} 2$ is rejected which can mean that partially Profitability has a significant influence on tax avoidance. Profitability ratios are proxied by Return on assets (ROA) which can provide an overview of the net profit / net profit obtained from the use of assets. If the higher return on assets ratio, the effective tax rate will be lower, the lower ETR indicates high tax avoidance activities. This can occur because the tax with company profits is directly proportional, if the company's profitability increases indicates the better performance of the company and the greater the profit generated by the company, then automatically it can affect the existence of a higher tax burden.

Effect of Debt to Asset Ratio (DAR) on Tax Avoidance. Based on the t test the Debt to Asset Ratio variable has a tcount of 2.845 greater than ttable 2.05954 with a significant value of 0.009 smaller than the significant value that has been determined which is 0.05 . This shows that $\mathrm{Ha} 2$ is accepted and $\mathrm{Ho} 2$ is rejected which can mean that partially Debt to Asset Ratio (DAR) has a significant influence on tax avoidance. Debt To Asset Ratio (DAR) is one of the ratios to measure the solvency level of a company, namely to see the company's ability to pay long-term obligations. Debt To Asset Ratio (DAR) is a debt ratio used to measure the ratio between total debt and total assets, meaning how much the company's assets are financed by company debt. A company that is said to be solvable if the company has sufficient assets and wealth to pay its debts. So, the lower the debt used in financing company assets, the company tends not to try to avoid tax evasion, and vice versa if the higher debt is used in financing company assets, the company can do tax avoidance through the payment of the debt.

Effect of Debt to Equity (DER) on Tax Avoidance.Based on the t test, the Debt to Equity (DER) variable has a account of 1.488 smaller than ttable 2.05954 with a significant value of 0.150 greater than the significant value that has been determined which is 0.05 . This shows that Ho3 is accepted and Ha3 is rejected which can mean that partially Debt to Equity (DER) does not have a significant effect on tax avoidance. Leverage ratio which is proxied by Debt to Equity Ratio (DER) is known to be able to compare all debt, including current debt with all Equity Debt to equity ratio, which is a ratio used to measure the proportion of debt to capital. So Debt to Equity (DER) does not affect tax avoidance, which means that the higher Debt to Equity (DER) will not affect tax avoidance activities in companies due to the higher level of debt of a company, the management will be more conservative in financial reporting. company operations

Effect of Profitability, Debt to Asset Ratio (DAR), and Debt to Equity (DER) on Tax Avoidance. Based on the F test where Fcount 4.679 is greater than Ftable 3.01 with a significant value of 0.010 smaller than the significant value that has been determined which is 0.05 . These results explain $\mathrm{Ha} 4$ accepted and Ho4 rejected which means simultaneously that there is an influence between Profitability, Debt to Asset Ratio (DAR), and Debt to Equity (DER) on Tax Avoidance in Manufacturing Industry Food and Beverage Sub Sector (Food and Beverage) ) registered on the Indonesia Stock Exchange in 2014-2017. The most dominant variable is the Debt to Asset Ratio (DAR) variable, this can be seen from the partial test (t) where the size of the company has tcount 2.845 with a significant value of 0.009. Where Debt to Asset Ratio (DAR) is a debt ratio used to measure the ratio between total debt and total assets, meaning how much the company's assets are financed by company debt. A company that is said to be a solvable if the company has sufficient assets and wealth to pay its debts. So, the lower the debt used in financing company assets, the company tends not to try to avoid tax evasion, and vice versa if the higher debt is used in financing company assets, the company can do tax avoidance through the payment of the debt. Then the second variable that has the dominant strength is Profitability, this can be seen from the partial (t) test where institutional ownership has tcount 2.438 with a significant value of 0.027 . Where the Profitability Ratio is proxied by Return on assets (ROA) which can provide an overview of the net profit / net profit obtained from the use of assets. If the higher return on assets ratio, the effective tax rate will be lower, the lower ETR indicates high tax avoidance activities. This happens because the tax with company profits is directly proportional, if the company's profitability increases indicates the better performance of the company and the greater the profit generated by the company then it affects the higher tax burden. These dominant variables can influence other variables

partially test does not affect tax avoidance. But if a simultaneous test is carried out, the three independent variables together have a significant effect on the dependent variable. In other words, if the Profitability Ratio, Debt to Asset Ratio (DAR), and Debt to Equity (DER) can be managed properly by the company, then it can increase company profits which indirectly will result in company management decisions in passing tax avoidance. 


\section{Conclusions and Suggestions}

Based on the results of the analysis and discussion that has been done, it is conc1. Profitability Profitability has a tcount of 2.438 greater than ttable 2.05954 with a significant value of 0.027 smaller than the significant value that has been determined which is 0.05 . This shows that Ha1 is accepted and Ho2 is rejected which can mean that partially Profitability has a significant influence on tax avoidance

2. Debt to Asset Ratio (DAR)

Debt to Asset Ratio (DAR) has a tcount of 2.845 greater than ttable 2.05954 with a significant value of 0.009 smaller than the significant value that has been determined which is 0.05 . This shows that Ha2 is accepted and $\mathrm{Ho} 2$ is rejected which can mean that partially Debt to Asset Ratio (DAR) has a significant influence on tax avoidance

3. Debt to Equity (DER)

Debt to Equity (DER) has a tcount of 1.488 smaller than ttable 2.05954 with a significant value of 0.150 greater than the significant value that has been determined which is 0.05. This shows that Ho3 is accepted and Ha3 is rejected which can mean that partially Debt to Equity (DER) does not have a significant effect on tax avoidance.

\section{Profitability, Debt to Asset Ratio (DAR), and Debt to Equity (DER)}

Profitability, Debt to Asset Ratio (DAR), and Debt to Equity (DER) have a simultaneous effect on Tax Avoidance. Where Fcount 4.679 is greater than Ftable 3.01 with a significant value of 0.010 smaller than the significant value that has been determined which is 0.05 . These results explain $\mathrm{Ha} 4$ accepted and Ho4 rejected which means simultaneously that there is an influence between Profitability, Debt to Asset Ratio (DAR), and Debt to Equity (DER) on Tax Avoidance in Manufacturing Industry Food and Beverage Sub Sector (Food and Beverage) ) registered on the Indonesia Stock Exchange in 2014-2017. The two dominant variables are Debt to Asset Ratio (DAR) and Profitability can affect other variables that are not partially influential. Therefore the Ha4 hypothesis is accepted and Ho4 is rejected, which means that the independent variables simultaneously influence tax avoidance.

For other researchers who want to examine the same title, the researchers suggest for further research to be able to add and use other variables that can add knowledge to the community of use.

\section{Reference}

Arthur J.Keown; John D.Martin; J William Petty; David F.Scott,Jr (2008). “Manajemen Keuangan: Prinsip dan penerapan”. Edisi ke Sepuluh. Penerbit: PT. Indeks, Cetakan Pertama. ISBN: 0-13-145065-4. Indonesia.

Amin, Teguh, Sapto. (2015). “Pajak Terapan Brevet AB”. Jakarta: Taxsys.

Angel Rica Febriani (2018). "Pengaruh Return on Aset, Leverage dan Sales Growth Terhadap Tax Avoidance. (Studi Empiris pada perusahaan industri Manufaktur sub sektor Makanan \& minuman yang terdaftar di BEI tahun 20212-2016).

Brigham, Eugene F., dan Houston, Joel F. (2006). Dasar-Dasar Manajemen Keuangan, Buku 2 Edisi 10. Jakarta: Salemba Empat.

Bela Sandra Pratiwi (2018), Pengaruh profitabilitas dan leverage terhadap Tax Avoidance (studi pada perusahan maunfaktur subsektor otomatif dan komponem yang terdaftar di BEI 2012-2016).

Cahyono, Deddy Dyas d.k.k, (2016). Pengaruh Komite Audit, Kepemilikan Institusional, Dewan Komisaris, Ukuran Perusahaan, Leverage dan Profitabilitas Terhadap Tax Avoidance Pada Perusahaan Perbankan yang Listing di BEI Periode Tahun 2011-2013. Journal of Accounting, Volume 2 No.2 Maret 2016.

Citra Janiencia Setiani (2016), Analisis Faktor-Faktor yang mempengaruhi Tax Avoidance, Studi Kasus pada perusahaan Pertambangan di BEI tahun 2011-2014

Chairil Anwar Pohan, 2015. “Manajemen Perpajakan“, PT. Gramedia Pustaka Utama, Jakarta. 
Chen, S., Chen, X., Cheng, Q dan Shevlin, T. (2010). “Are Firms More Tax Aggressive Than Non-Family firms?”. Jurnal Of Financial Economic., 95,

41-61.

David Wijaya.(2016). "Praktikum Manajemen Keuangan: Berbasis IFRS”. Penerbit Mitra Wacana Media ISBN: 978-602-318-171-1, Jakarta.

Deddy Dyas Cahyono.,Rita Andini dan Kharis Raharjo (Maret 2016), Pengaruh Komite Audit, Kepemilikan Institusional, Dewan Komisaris, Ukuran perusahaan (Size), Leverage (DER) dan Profitabilitas (ROA) terhadap Tindakan Penghindaran Pajak (Tax Avoidance) pada Perusahaan Perbankan yang listiing BEI Periode tahun 20112013. Journal of Accounting Volume 2 No.2.

Dewinta, Ida Ayu Rosa dan Setiawan, Putu Ery. (2016). "Pengaruh Ukuran Perusahaan, Umur Perusahaan, Profitabilitas, Leverage, dan Pertumbuhan Penjualan terhadap Tax Avoidance”. E-Jurnal Akuntansi Universitas Udayana, Vol 14.3, hal 1587.

Erwan Agus Purwanto, Dyah Ratih Sulistyastuti (2011). “Metode penelitian kuantittatif untuk Administrasi Publik dan Masalah-masalah Sosial”. Penerbit Gava Media ISBN:979-1078-11-4

Fahmi, Irham. 2015. “Analisis Laporan Keuangan”. Bandung: Alfabeta

Fajar Arif F (2017), "Pengaruh Return On Asset,Leverage, Corporate Governance, Ukuran Perusahaan, dan Kompensasi Rugi Fiskal terhdap Tax Avoidance". Studi empiris pada perusahaan yang terdaftar di BEI tahun 2012-2015).

Fertika Nofisa Putri (2014). "Pengaruh Karakteristik Kepemilikan dan Kompensasi eksekutif terhadap tax aggressive". Studi banding pada perusahaan manufaktur yang terdaftar di BEI. Univetsitas Negeri Padang.

Fitria Maharani Al Rozi. (2017).” Analisis Faktor-fator yang mempengaruhi Ukuran Tax Avoidance pada perusahaan industri Barang konsumi yang terdaftar di BEI.

Ghozali, Imam. (2013). "Aplikasi Analisis Multivariet Dengan Program IBM SPSS 21 Update PLS Regresi", Semarang: Badan Penerbit Universitas Diponegoro.

Giawan Nur Fitria (2018), Pengaruh Kepemilikan Institusional, komisaris Independen, karakter eksekutif dan size terhadap Tax Avoidance, (Study Empiris Pada Emiten Sektor Perdagangan yang Terdaftar di BEI Tahun 2014-2017, Profita: ISSN: 2086-7662 Vol. 11 No. 3 Desember 2018 e-ISSN: 2622-1950

Hasibuan, Zainal,A. (2007). “Metodologi Penelitian Pada Bidang Ilmu Komputer Dan Teknologi Informasi, Konsep, Teknik dan Aplikasi, Jakarta. Fakultas Ilmu Komputer Universitas Indonesia.

Harahap, Sofyan Syafri. (2013). “Analisis Kritis Atas Laporan Keuangan”, Jakarta: Cetakan Kesebelas, Penerbit Rajawali Pers.

Hidayat, Wastam Wahyu. (2018). "Pengaruh Profitabilitas, Leverage, dan Pertumbuhan Penjualan Terhadap Penghindaran Pajak Studi Kasus Perusahaan Manufaktur di Indonesia”. Jurnal Riset Manajemen dan Bisnis Fakultas Ekonomi UNIAT, Vol.3, No.1,Februari 2018: 19-26.

Hutagaol, John. (2007). “Perpajakan : Isu - Isu Kontemporer, Edisi pertama”. Yogjakarta: Graha Ilmu.

http://ciungtips.com/2015/01/apa-itu-profit-margin.html, Apa itu Profit Margin? Rian Ciung diposting tgl 20 Januari 2015 (diakses pada tgl 21 Agustus 2018)

https://id.wikipedia.org/wiki/Manajemen_keuangan. "Manajemen keuangan".(diakses pada tanggal 23 Agustus pukul 19.28 WIB)

https://id.wikipedia.org/wiki/Profitabilitas (diakses pada tanggal 20 Agustus pukul 19.28 WIB)

http://ekonomibanget.blogspot.com/2015/11/definisi-operating-profit-margin.html. Heru Permana (diakses tgl 24 Agustus 2018). 
Vol.11, No.16, 2019

http:// http://www.bpk.go.id/lkpp. (diakses pada tanggal 20 Desember 2017 pukul 10.03 WIB) 
https://datakata.wordpress.com/2015/10/17/teori-sinyal-signalling-teory/ Teori Sinyal (Signalling Teory) (Posting 17 Okt 2015) (diakses pada tgl 23 Agustus 2018.

https://tirto.id/delapan-strategi-menkeu-tingkatkan-penerimaan-pajak-csXZ, Damianus Andreas - 18 Juli 2017 (diaksses pada tanggal 20 Agustus 2018 jam 18:42 WIB)

https://ilmumanajemenindustri.com/pengertian-roa-return-assets-rumus-roa-pengembalian-aset/ Pengertian ROA (Return On Asssets) dan Rumus ROA. Diposting Oktober 23,2017 (Diakses pada tgl 22 Agustus 2018) http://sinarlestarimarbun.blogspot.com/2012/11/manajemen-perpajakan.html. "Majalah Hukum manajemen Pajak". November 1, 2012 (Diakses pada tgl 26 Agustus 2018).

https://qiyaraconsulting.wordpress.com/2016/06/10/bagaimana-cara-perusahaan-menghindari-pajak-danbagaimana-mengetahui-dan-mengukurnya/. Andi Priandoyo.Publikasi 10 Juni 2010 (Diakses pada tgl 26 Agustus 2018).

http://bilongtuyu.blogspot.com/2013/05/pengertian-debt-to-total-assets-ratio.html. Dormatio Rumapea (diakses pada tgl 26 Agustus 2018.

https://id.wikipedia.org/wiki/Analisis_regresi. “Analisis Regresi”. (Diakses pada tgl 27 Agustus 2018).

http://duwiconsultant.blogspot.com/2011/11/analisis-regresi-linier-berganda.html. "Analisis Regresi Linier Berganda”. Duwi Consultant (Nov 2011). (Diakses pada tgl 27 Agustus 2018).

https://metodepenelitiana.wordpress.com/desain-penelitian-1/. Desain Penelitian (1) (Diakses pada tgl 27 Agustus 2018).

https://ekonomi.kompas.com/read/2014/06/13/1135319/Coca-Cola.Diduga.Akali.Setoran.Pajak, Adinda Ade Mustami, diposting 13/06/2014 (diakses pada tgl 22 Febr 2018).

http://riskymahira.blogspot.com/2012/11/perencanaan-pajak-tax-planning.html, Risky Mahira, diposting 13 November 2012,(diakses pada tgl 23 Februari 2019).

I Gusti Ayu Cahya Maharani dan Ketut Alit Suardana (2014). "Pengaruh Corporate Governance, Profitabilitas, dan Karakteristik Eksekutif pada Tax Avoidance Perusahan Manufaktur. ISSN:2302-8556, E-Jurnal Akuntansi Universitas Udayana 9.2 (2014): 525-539.

Ibnu Wijaya. (2014). "Mengenal Penghindaran Pajak". Diakses Melalui: http://www.pajak.go.id/content/article/mengenal-penghindaran-pajak-taxavoidance.

Kasmir. 2015. “Analisis Laporan Keuangan”. Jakarta : PT Raja Grafindo Persada.

Jensen \& Meckling, 1976, The Theory of The Firm: "Manajerial Behaviour, Agency Cost, and Ownership Structure”. Journal of Financial and Economics, 3:305-360

Kurniasih, Tommy dan Maria M. Ratna Sari. (2013). "Pengaruh Return On Asset, Leverage, Corporate Governance, Ukuran Perusahaan, dan Kompensasi Rugi Fiskal pada Tax Avoidance". Buletin Studi Ekonomi Vol 18, No. 1, 58-65.

Lanis, Roman dan Grant Richardson. (2013). “Corporate Social Responsibility and Tax Aggressiveness: A Test of Legitimacy Theory”. E-Jurnal Accounting, Auditing and Accountability Journal Vol. 26, No. 1, 2013.

Mardiah Nursani, Diamonalisa, Edi Sukarmanto (2017). "Pengaruh Profitabilitas, Leverage, dan Kepemilikan Institusional terhadap Tax Avoidance (Studi Empiris Pada Perusahaan Kimia yang terdaftar di BEI pada periode 2009-2016)." Prosiding Akuntansi.ISSN:2460-6561. Volume 3, No.2, tahun 2017.

Otamawati, Mayarisa. Pengaruh Karakter Eksekutif, Komite Audit, Ukuran Perusahaan, Leverage, Pertumbuhan Penjualan, dan Profitabilitas Terhadap Tax Avoidance. Jurnal Akuntansi Bisnis, Vol.XV No.30 Maret 2017. 
Puspita. Deanna dan Meiriska Febrianti. (2017). "Faktor-Faktor Yang Mempengaruhi Penghindaran Pajak Pada Perusahaan Manufaktur Di Bursa Efek Indonesia”. Jurnal Bisnis dan Akuntansi STIE Trisakti. Vol. 19, No. 1, 3846.

Putu Winning Arianndini dan I Wayan Ramantha (2018). "Pengaruh Profitabilitas, Leverage, dan Kepemilikan Institusional pada Tax Avoidance” ISSN: 2302-8556, E-Jurnal Akuntansi Universitas Udayana, Vol.22.3

Putri, Scania Putri. (2016). "Pengaruh Ukuran Perusahaan, Return On asset ( ROA), Leverage, dan Intensitas Modal Terhadap Tarif Pajak Efektif “.JOM Fakultas Ekonomi Universitas Riau. Vol 3, No 1, Tahun 2016, Hal 1506-1519.

Rahayu, Kurnia Siti. (2013). “Perpajakan Indonesia. Yogyakarta: Graha Ilmu.

Rosalia, Yuliesti. (2017). Pengaruh Profitabilitas, Likuiditas dan Corporate Governance Terhadap Penghindaran Pajak. Jurnal Ilmu dan Riset Akuntansi. STIESIA Surabaya.

Rusli Reinaldo. (2017). "Pengaruh Leverage, Ukuran Perusahaan, ROA, Kepemilikan Institusional, Kompensasi Kerugian Fiskal, dan CSR Terhadap Tax Avoidance Pada Perusahaan Manufaktur Sub Sektor Makanan dan Minuman Terdaftar di BEI 2013-2015. Faculty of Economics Riau University. Vol.4, No.1.

Rezaei, Farzin dan Mohsen Ghanaeenejad. (2014). "A Review On Transparency In Finanacial Reporting And Its Effects On Tax Avoidance And Firm Value”. E-Jurnal Of Commerce and Accounting Research. Vol 3, Issue 4, 2014.

Santoso, Singgih. (2012). “Analisis SPSS pasa Statistik Parametrik”. Jakarta: PT. Elex Media Komputindo.

Saputra, Moses Dicky Refa dan Asyik, Nur Fadjrih. (2017). "Pengaruh

Profitabilitas, Leverage Dan Corporate Governance Terhadap Tax Avoidance. Jurnal Ilmu dan Riset Akuntansi, vol 6, no 8, 2017.

Suandy, Erly. (2016). “Perencanaan Pajak”. Jakarta: Salemba Empat.

Sudirman Rismawati, SE.,M.SA dan Amiruddin Antong, SE.,M.Si, (2012). "Perpajakan Pendekatan Teori dan Praktik”. Malang: Empat Dua Media.

Sugiyono. (2016). “Metode Penelitian Kuantitatif, Kualitatif dan R\&D”. Bandung: Alfabeta.

Supramono dan Theresia Woro Damayanti. (2010). “Perpajakan Indonesia”. Yogyakarta: Andi Offset.

Sumadi Suryabrata (1983).”Metodologi Penelitian". Penerbit: PT. RajaGrafindo Persada.ISBN:979-421-104-4.

Swigly. Calvin dan I Made Sukartha. (2015). "Pengaruh Karakter Eksekutif, Komite Audit, Ukuran Perusahaan, Leverage, dan Sales Growth pada Tax Avoidance”. E-Jurnal Akuntansi Universitas Udayana 10.1 (2015): h:47-T 62.

Safirra Salsa Nabilla, Iman Zulfiktri (2018). "Pengaruh Risiko Perusahaan, Leverage (Debt to Equity Ratio) dan pertumbuhan Penjualan Terhadap penghindaran pajak (tax avoidance) Studi empiris pada perusahaan Manufaktur subsektor makan \& minuman yang terdaftar di BEI tahun 2014-2017).

Tarmidi, D. (2019). Tax Compliance and Uncompliance Entity: A Comparative Study of Investor Reaction, International Journal of Academic Research in Accounting, Finance and Management Sciences 9(1): 105-110

Undang-Undang Republik Indonesia Nomor 28 Tahun 2007 tentang Ketentuan Umum dan Tata Cara Perpajakan.

Undang-Undang Republik Indonesia Nomor 36 Tahun 2008 tentang Perubahan Keempat atas Undang-Undang Nomor 7 Tahun 1983 tentang Pajak Penghasilan.

Utari, Ni Kadek Yuliani Utari dan Ni Luh Supadmi. PENGARUH Corporate Governance, Profitabilitas dan Koneksi Politik Pada Tax Avoidance. E- Jurnal Akuntansi Universitas Udayana. Vol.18.3. Maret 2017. 
Yulfaida dan Zhulaikha. (2012). "Pengaruh Size, Proftabilitas, Profile, Leverage

Dan Ukuran Dewan Komisaris Terhadap Pengungkapan Tanggung Jawab Sosial Pada Perusahaan Manufaktur Di Bursa Efek Indonesia". Semarang: UNDIP, DIPONEGORO JOURNAL OF ACCOUNTING Volume 1, Nomor 2, Tahun 2012, Halaman 112, http://ejournal-s1.undip.ac.id/index.php/accounting.

Yunanda, Derick dan Saifudin. (2016). “Determinasi Return On Asset, Leverage,

Ukuran Perusahaan, Kompensasi Rugi Fiskal, dan Kepemilikan Institusi

Terhadap Penghindaran Pajak”. Jurnal Penelitian Ilmu Ekonomi WIGA

Vol. 6, No 2, Tahun 2016, Hal 131-143.

Waluyo (2017), The effect of good corporate governance on tax avoidance: empirical study of the Indonesian Bangking Company.the Accounting Journal of Binaniaga Vol.02.No.02, Des 2017, PISSN:2527-4309, EISSN:2580-1481.

Waluyo (2017), "Perpajakan Indonesia (Edisi 12 Buku 1)”, Salemba Empat, Jakarta. 